\title{
Sportmen's experiences at a somatology clinic receiving a sport message
}

\begin{abstract}
Authors:
Karien Jooste

Valencia Khumalo ${ }^{2}$

Jeanette Maritz ${ }^{3}$

Affiliations:

${ }^{1}$ School of Nursing, Faculty of Community and Health Sciences, University of the Western Cape, South Africa

${ }^{2}$ Department of Somatology, University of Johannesburg, South Africa
\end{abstract}

${ }^{3}$ Faculty of Health Sciences, University of South Africa

\section{Correspondence to:}

Karien Jooste

Email:

kjooste@uwc.ac.za

Postal address:

Postnet Suite \#155, Private Bag X16, Hermanus 7200 ,

South Africa

Dates:

Received: 24 Nov. 2011

Accepted: 07 Feb. 2013

Published: 03 June 2013

How to cite this article: Jooste, K., Khumalo,

V. \& Maritz, J., 2013 'Sportmen's experiences at a somatology clinic receiving a sport message', Health SA Gesondheid, 18(1), Art \#637, 9 pages. http://dx.doi. org/10.4102/hsag.v18i1.637

\section{Copyright:}

(C) 2013. The Authors. Licensee: AOSIS

OpenJournals. This work is licensed under the Creative Commons Attribution License.

Read online:
Sportsmen are increasingly visiting somatology clinics for massages prior to an aerobic sports event. Massage is frequently utilised prior to an athletic activity, as a means of enhancing performance. Massage is known to have both calming and stimulating properties, thereby possessing the potential to benefit performance in numerous different circumstances. In the context of sportsmen visiting somatology clinics, it is unclear how men experienced the benefits of a massage by a therapist in the somatology environment, prior to participating in an aerobic sports event. The purpose of this qualitative, exploratory, descriptive and contextual study was to explore and describe the experiences of men regarding sports massage in a somatology clinic prior to an aerobic sports event. Purposive sampling was used to select eight (8) men, aged between 25 and 50 years, who received two massages within two weeks prior to participating in an aerobic sports event. The data were collected through in-depth, unstructured, individual interviews and field notes until saturation of data was achieved. Trustworthiness was ensured by utilising the principles of Lincoln and Guba's model. The men experienced the sports massage as relaxing and giving perceived holistic beneficial effects. They described their experience during the massage and during and after participation in an aerobic sports event. A sports massage brings about psychological, physical, and spiritual effects during and after participation in an aerobic sports event.

Sportsmanne besoek toenemend somatologieklinieke vir masserings voor 'n aërobiese sportsbyeenkoms as 'n manier om prestasie te bevorder. Massering is bekend vir beide die kalmerende en stimulerende eienskappe daarvan, en daarom beskik dit oor potensiële voordele vir prestasie in verskeie omstandighede. In die konteks van sportsmanne wat somatologieklinieke besoek, is dit steeds onduidelik hoe mans die voordele van ' $n$ massering by 'n somatologieterapeut voor hul deelname aan 'n aërobiese sportsbyeenkoms ervaar. Die doel van hierdie kwalitatiewe, ondersoekende, beskrywende en kontekstuele studie was om die ervaringe van mans ten opsigte van 'n sportsmassering in 'n somatologiekliniek voor 'n aërobiese sportsbyeenkoms te ontdek en te beskryf. Doelbewuste steekproefneming is gebruik om agt mans, tussen 25 en 50 jaar oud, wie twee masserings binne twee weke voor deelname aan 'n aërobiese sportsbyeenkoms ontvang het, te selekteer. Die data is deur in diepte, ongestruktureerde onderhoude en veldnotas ingesamel totdat dataversadiging bereik is. Vertrouenswaardigheid is deur die gebruik van die beginsels van Lincoln en Guba se model verseker. Die mans het hul ervaring tydens die massering, asook tydens en na hul deelname aan die aërobiese sportsbyeenkoms, beskryf. Hulle het die sportsmassering as ontspannend ervaar wat holisties voordelige effekte meebring. Die massering het psigologiese, fisiese en geestelike voordele teweeggebring.

\section{Introduction}

Massage therapy gained a foothold in medicine some 150 years ago when many hospitals and clinics offered massage to their patients. Physicians often performed the procedure (Harvard Men's Health Watch 2006:7). As medicine grew more complex, nurses and physical therapists took over the task. Since the 1970s, massage has increasingly become the domain of alternative medicine.

Women visit somatology clinics for various reasons, including pampering, improvement and maintenance of health, as well as for protection of their skin. A new trend has emerged since sportsmen have become clients of somatology clinics. Sports massages are usually performed by sports therapists and the researcher became aware that somatology therapists perform sport massages, as more sportsmen are increasingly visiting somatology clinics. Part of this trend is men visiting somatology clinics specifically for massages prior to an aerobic sports event. Aerobic sports events refer to sports events such as boxing, squash, basketball, soccer, running 
and rugby. During these activities, there is increased oxygen consumption for metabolic processes in the body to take place. Massage is frequently utilised prior to an athletic activity as a means of enhancing performance (Gould 2004:1).

Somatology is a multi-disciplinary profession in which somatologists or somatology therapists (persons qualified to perform a massage in accordance with the Allied Health Professions Act, 63 of 1982, South Africa) treat a variety of skin and body conditions in a holistic manner. Holistic principles consider the individual in three dimensions, namely, body (physical structures and biological processes), mind (psychological processes) and spirit (a connection with deeper meaning and purpose in life) (Gould 2004:1).

Currently, there is a fair amount of controversy in literature about the way in which men relate to the psychological, physiological and spiritual outcomes of a massage. According to Aldrade and Clifford (2005:30-35), massage prepares sportsmen for physical activity rather than for psychological purposes. Massage can give athletes a soothing, sedative feeling after competition or an invigorating and energetic feeling precompetition. It is important for somatology therapists to understand and know how to perform the essential components of a massage to enhance the wellbeing of sportsmen holistically.

Draper and Tessier (2005:67) state that massage gives an athlete a psychological boost and greater body awareness and generates greater self-confidence. Psychologically, massage is beneficial because sportsmen are better able to relax and focus their attention on visualisation and concentration techniques in relation to their respective sporting event.

There seems to be a link between the mind and the body in that certain emotional or psychological states produce changes in the chemical balance of the body and are therefore able to influence the well-being of the body (Ogden 2012:421). A holistic approach to massage incorporates the link between the mind and the body. Stress is a relationship between a person and the environment that is appraised by the person as exceeding his or her resources and endangering his or her wellbeing (Lazarus \& Folkman 1984:21). The effects of stress during aerobic sports activities can be felt in the muscles of the neck or the back in the form of tension or soreness, anxiety or tension headaches. Receiving a massage can help alleviate stress in the body. People who work out extensively place a great deal of stress on their bodies, and massage can reduce that stress (Gould 2004:30).

With regard to physiological outcomes, Hart, Swanik and Tierney (2005:45-47) indicate that a massage is often used to help prepare for exercise, expedite recovery from muscle soreness, and enhance athletic performance. They further indicate that massage effectively reduces pain and swelling over time. Goodwin (2009:1028), in a study about the effect of preperformance lower-limb physical massages, found that the benefits of massage are to reduce pain and muscle spasms in the body.
The physiological emphasis of massage is aimed at correcting and balancing soft tissue integrity and creating traction between the skin and tissues below it. The benefits are that a massage will speed up recovery, reduce soreness and relieve pain in the body (Goodwin 2009:1020).

Weerapong, Hume and Kolt (2005:235) report that many coaches, athletes and sports medicine personnel believe, based on observations and experiences, that massage can provide several physiological benefits to the body; such as increased blood flow, reduced muscle tension and neurological excitability, and an increased sense of well-being.

During an aerobic sports event, there are a number of physiological adaptations that may occur in the body, some of which may primarily occur centrally or peripherally. Laffitte, Mille-Hamard and Koralsztein (2003:202) suggest that central adaptations include an improvement in the capacity of the heart to pump blood primarily due to increased stroke volume, which occurs as a result of an increase in enddiastolic volume and left ventricular mass. Subsequently, these adaptations result in an increased cardiac output.

Furthermore, there seems to be a link between the mind, body and spirit of a person during a massage, where meditation as part of spirituality is one technique that people use to unite the three aspects of their being in a helpful way. Meditation allows people to calm their minds while the body is relaxing during a massage, and it also supports a spiritual connection. Some individuals practise meditation in a rather formalised fashion while other people master it during massage sessions (Holey \& Cook 2003:4).

McMahon and Pearson (1998:102) conducted a qualitative study based on therapeutic touch developed in the USA by Krieger (1996:46), and highlighted that touch was a form of healing meditation. It would appear to have its roots in quantum physics and Eastern philosophy (Sayre-Adams, Wright \& Billey 1992:98). Brennan and Heisser (1988:76) describe studies about energy fields, while Benor (2004:56) found that healing in the form of massage could be accepted as effective a treatment as certain pharmaceutical drugs.

Spirituality in sport may go beyond the religious perspective of a person, creating meaning and purpose in life (Helminiak, 1996:19). With regard to performance excellence in sports, Ravizza (2002:14) suggests that '... when physical, mental and emotional components join together, movement takes on a spiritual dimension in the sense of purpose that is attained'. In a broader context, spirituality could also refer to an athlete's close relationships, or extraordinary and self-affirming moments in life, such as winning an Olympic medal, or securing a personal best achievement. Many authors acknowledge that spirituality involves an individual's search for meaning in life, wholeness, peace, individuality and harmony (Leary \& Tangney 2003:146). Therefore, spirituality is viewed as an integral component of being human (Narayasamy 1999: 274). 
This study aimed at exploring and describing the experiences of sportsmen who receive a massage at a somatology clinic prior to an aerobic sports event. These could assist somatology therapists to understand how a massage could enhance the wellbeing of sportsmen holistically.

\section{Problem statement}

No research or literature could be found about the experiences of sportsmen who receive a massage at a somatology clinic. However, a new trend has evolved of sportsmen who are increasingly becoming clients at somatology clinics. Men who visit somatology clinics specifically for massage prior to an aerobic sports events form part of this trend. However, their experiences are unclear. The research question asked was:

- How do men experience a massage, performed by a somatology therapist at a private somatology clinic, prior to participating in an aerobic sports event?

\section{Objectives of the study}

The objective of the study was:

- To explore and describe the experiences of men who receive a massage at a somatology clinic prior to an aerobic sports event.

\section{Research design}

A qualitative, exploratory, descriptive and contextual design was used. Qualitative research provides the opportunity to gain a detailed understanding of issues (Creswell 2007:40). An exploratory design was used to gain insight into, and an understanding of, the experiences of men receiving a massage at a somatology clinic prior to an aerobic sports event. Coffey (2004:325) states that a descriptive study aims at providing an accurate and precise description of experiences. He further suggests that one cannot separate people's experiences from the context in which they have those experiences. The researcher explored and described the experiences of men receiving a massage prior to an aerobic sports event within the context of a private somatology clinic.

\section{Research method Population and sampling}

The accessible population in this study consisted of men who received a massage at a somatology clinic prior to an aerobic sports event in the Johannesburg metropolitan area. Purposive sampling was used, which, according to Maree and Ellias (2007:198), is based on the judgment of the researcher in choosing the sample that has elements which are of interest for study. The sample in this study included eight men (four Black, two Coloured and two White) who complied with the following criteria:

- They had two massages within two weeks prior to participating in an aerobic sports event.

- They were between the ages of 25 and 50 years, and

- They participated in an aerobic sport such as boxing, squash, basketball, soccer, running and rugby.
The researcher invited men who visited the clinic to take part in the study, and collected data until saturation of data was reached. This meant that the researcher continued the research until no new information emerged (Creswell 2007:161).

\section{Data collection}

In order to conduct the research, in-depth, unstructured, individual interviews were held during July 2010. An indepth, unstructured, individual interview of around 20 to 50 minutes allowed the interviewer to access the deeper meaning of the participant's responses to massage (Burns \& Grove 2005:422). The interviews were also useful since the participants found it easier to express their experiences verbally as opposed to engaging in writing or filling in questionnaires. Additionally, the meaning of participants' responses could be clarified immediately while the interviews led to a greater response rate and offered the opportunity to attain highly personalised data (Flick 2009:156). The researcher conducted the interviews in a private room.

The same central open-ended question was asked of all participants: 'How do you experience a massage performed by a therapist at a somatology clinic prior to an aerobic sports event?' The question was then followed by probing, to explore the experiences of participants about these massages more extensively (Burns \& Grove 2005:814). In addition to the research question, the researcher created a fact sheet. This was a page at the beginning of the notes that contained information such as the date, place of interview, characteristics of interviewee, and content of the interview (Neuman 2006:406).

The researcher suspended her own judgment about the phenomenon. By using bracketing, researchers do not allow their assumptions to shape the data collection or impose their understanding and constructs on the data (Hamill \& Sinclair 2010:16). The researcher listened attentively and recorded the men's responses using an audio recorder to capture all interview sessions so as to increase the credibility of the study.

\section{Data analysis strategies}

Data analysis entailed categorising, ordering and summarising the data and describing it in meaningful terms. Recorded interviews were transcribed and analysed by using Tesch's inductive, descriptive coding technique (in Creswell 2003:185). Transcribed interviews and field notes were treated as text reference for interpretive analysis purposes.

The researcher obtained a comprehensive sense of the phenomenon by reading through the transcripts. The researcher randomly selected one interview at a time while asking: 'What is this about?' and thinking about the underlying meaning of the information. Any thoughts that came to mind were jotted down. When the researcher had completed the task for several respondents, a list was 
compiled of all the topics that had emerged. Similar topics were clustered together and formed into columns that might be arranged into major topics and exceptional responses. The researcher then took the list and returned to the data, and tested a preliminary organising scheme to establish whether any new categories and codes emerged. The most descriptive wording for the topics was then turned into categories. Lines were drawn between categories to show relationships. The researcher made a final decision about the abbreviations for each category and alphabetised the codes. The data that belonged to each category were assembled in a group and a preliminary analysis was performed.

Raw data, transcribed audio recordings of the interviews, field notes and the protocols for data analysis were given to an independent cocoder, who was an experienced qualitative researcher. The independent cocoder was given protocols with guidelines for the data analysis. After the independent cocoder had analysed the data separately from the researcher, a consensus meeting was held (Green \& Thorogood 2009:117).

\section{Trustworthiness of the study}

Trustworthiness was maintained by using Lincoln and Guba's (Creswell 2007:203) model of criteria, which incorporates credibility, transferability, confirmability, dependability and authenticity (Guba \& Lincoln, in Denzin \& Lincoln 2005:205).

Credibility requires an adequate immersion in the research setting to enable recurring patterns to be identified and verified (Krefting 1991:218). In this study, credibility was facilitated by prolonged engagement with the men prior to their interviews, by building trust on the basis of honouring anonymity, honesty and openness. The interviews lasted between 20 and 50 minutes. The researcher collected data until saturation of data occurred.

Reflexivity refers to the assessment of the influences of the researcher's own background, perceptions, and interests on the qualitative research process (Collins, Onwuegbuzie \& Jiao 2010:106). The researcher made use of a reflective journal in which she reviewed and reflected on situations, including interviews with the participants. The bracketing process enabled the researcher to identify in what ways new knowledge could be utilised within other situations, such as during subsequent interviews (Wall, Glenn, Mitchinson \& Poole 2004:22). A debriefing interview was conducted to assess what influence the researcher's own perceptions and interests had on the study (Onwuegbuzie, Leech \& Collins 2008:3).Referential adequacy was captured by means of field notes and audio recordings of all the in-depth unstructured individual interview sessions (Babbie \& Mouton 2001:276). Triangulation was achieved by using multiple data collection methods of interviewing and field notes.

Transferability refers to the extent to which the findings of the study can be transferred to another context, or with other participants (De Vos, Strydom, Fouché, \& Delport
2005:346). In this study, a complete, dense description of the methods used for conducting the in-depth unstructured individual interviews was supplied. In addition, the setting, the population and sampling method used were completely described. This was done to ensure that future researchers have the necessary information to replicate the research if the need should arise.

Confirmability refers to the degree to which the findings are uniquely a result of the conditions of research and not of other biases, motivation or perspectives (Krefting 1991:216). In this study, confirmability was ratified by the involvement of the independent coder (Babbie \& Mouton 2001:278). The indepth, unstructured, individual interviews were supported by written field notes and the use of an audio recorder (De Vos et al. 2005:346).

The concept of dependability refers to the consistency of research findings in a qualitative study. Indirectly, the measures of credibility ensure dependability (Babbie \& Mouton 2001:278). Dependability in this study was ensured by the cocoding procedure, which required an independent cocoder to recode the findings during the data analysis phase. Furthermore, dependability was also ensured by a thick description of the research methods, sampling process and data analysis.

Authenticity is a feature that is unique to naturalistic inquiry; it is believed to be displayed when researchers show qualities such as fairness, which takes their own concerns, issues and any underlying values into account. In this study, ontological authenticity, educative authenticity and tactical authenticity were observed.

Guba and Lincoln in Denzin and Lincoln (2005:207) consider fairness to be a quality of balance; meaning that all participants' views, concerns, voices and perspectives are apparent in the text. The fairness was defined in this study by deliberate attempts to prevent marginalisation, to act affirmatively with regard to the inclusion and to act with energy to ensure that all the voices within the study were represented in the text and that their data were treated fairly. In this study, multiple voices, concerns and views were allowed to surface by the researcher, who displayed a non-judgemental and open attitude. To further ensure authenticity, the researcher displayed fairness by clarifying what she wanted to explore. This was done by means of consent letters, which clearly indicated the objectives of the study as well as ensuring that the potential participants knew what the research was about.

\section{Ethical considerations}

Ethical clearance was obtained from the academic ethics committee of a university in Johannesburg (AEC 2009). The participants had a right to privacy, which implied that each participant had a right to decide when, where, to whom and to what extent the data would be revealed (Singleton, Straits, Straits \& McAllister 1988:454). The participants were 
informed that the only people who would handle the data were the supervisor, cosupervisor, the transcriber of the audio recorded interviews and the independent cocoder. The privacy aspect was also adhered to by interviewing the participants in a private venue without any other people present (Mouton 2001:244).

The names of the participants and other identifiers were not revealed in order to protect the privacy of participants. Confidentiality agreements were signed with the transcriber and independent cocoder. The identity of participants or sites was not revealed in any published accounts (Green \& Thorogood 2009:70).

Participants were legally and psychologically competent to give consent and were also aware of the fact that they were at liberty to withdraw from the study at any time. None of the participants were pressured into participating in this study. Therefore, their participation was voluntary. In this study, emotional harm was not foreseen since the topic was not of a sensitive nature, nor were the participants seen as a vulnerable group. The participants were not exposed to any physical, legal, social or economic harm. The participants were thoroughly informed beforehand about the potential impact of the study. Participants could withdraw from the study at any stage of the research project, without fear of victimisation or penalty.

Quotations from the participants are provided in italics. Some expressions used by the participants are colloquialisms and have been retained in the quotations. Since the quotations are provided verbatim, some possibly contain grammatical errors. Field notes are incorporated in the quotations in brackets where necessary for the purpose of clarifying the meanings of the quotations.

\section{Findings}

A summary of the findings and verbatim quotations are presented in Table 1. The main theme relates to men who experience the massage as 'relaxing'; or perceive holistically beneficial effects. Their experiences during the massage, during the aerobic sports event and after the aerobic sports event are described. The benefits were of a psychological, physical, and spiritual nature. Each category and subcategory will now be discussed separately. The psychological dimension seemed to receive the most attention as indicated by the number of quotations and references in the data sets.

Relaxation appears to be the single most important benefit of massage and results in perceived holistic beneficial effects. Relaxation can be defined as an enjoyable activity; a form of activity that provides a change and relief from effort, work, or tension, and gives pleasure (Concise Oxford English Dictionary 2004: 1121). Participants indicated the holistic nature of the massage, which included psychological (mind), physical (body) and spiritual effects.

\section{During the massage}

The participants experienced massage as being very relaxing while they were receiving the massage. The participants indicated that they experienced psychological effects relating to their minds and emotions. They felt that the massage enabled them to focus on the objectives of the massage, which were aimed at enhancing their performance as well as relaxing. They felt the massage eliminated their negative thoughts and noted that their minds cleared while they were receiving the massage treatment (Quotation 1). Tactile stimulation in body tissues contributes to complex neuro-hormonal responses in the hypothalamic-pituitary axis to circuit through the central nervous system pathways. The stimulus is dispersed through the cortex, midbrain and lower brain and interpreted as a relaxation response (Lawton 2003:86).

The massage further assisted the participants with reducing their stress levels (psychological) and the physical stress that they were experiencing in relation to their aerobic sports events (Quotation 2). Physiologically, adaptation to stress can be regulated by the capability of the hypothalamic-pituitary axis to secrete hormones, such as cortisol and endorphins, that ultimately decrease sympathetic nervous system activity and increase the response of the parasympathetic nervous system (Moyer \& Diem 2004:189).

This supports the finding of Weerapong et al. (2005:245) that massage assists sportsmen by promoting relaxation through psychological mechanisms. Tessier (2005:67) highlights that psychologically massage is valuable because the sportsmen are better able to relax (body) and focus attention on visualisation and concentration techniques for their upcoming sporting competitions.

The findings indicated that physical effects were experienced while the muscles were warming up. The sportsmen expressed that warming up seemed to have been an important part of the preparation stages prior to an aerobic sports event, since it reduced the chances of injuring their muscles. The warming up of muscles could be a result of increased circulation brought about by massage (Quotation 3). Callagan (1993:28) confirms that active warm-up and stretching are more effective for increasing flexibility than massage. Therefore, it is vital to bear in mind that preventative massage should be used as an adjunct to physical warm-up, rather than as a substitute. The goals of massage before a sporting event are to create a state of physiological readiness for the athlete, since massage is believed to stimulate circulation and to generate an increase in oxygenated blood to the area being massaged, creating a state of hyperaemia (Pike 1997:45). The body interacts with the state of readiness of a sportsman.

During the course of the massage treatment, the participants expressed experiencing a release of muscular tension (Quotation 4). Some sportsmen, however, found the experience painful (Quotation 5). Carpentier (2010:53) indicates that the more intense the massage techniques 
TABLE 1: Massage is a 'relaxing' experience, resulting in holistically beneficial effects.

\begin{tabular}{|c|c|c|}
\hline Category & Sub-category & Quotation \\
\hline \multirow[t]{2}{*}{ During the massage } & Psychological effects & $\begin{array}{l}\text { 1. 'You feel relaxed, you're, you're thinking about what the person is doing to you, it just sort of... you just feel... all } \\
\text { the issues of yours is just being drained or being massaged out, and that's how you feel'. } \\
\text { 2. 'It felt good, because ... because ... uhm ... I wasn't under any stress. I was ... I was relaxed a lot'. }\end{array}$ \\
\hline & Spiritual effects & $\begin{array}{l}\text { 8. 'But at some part allows you to also feel a sense of harmony about the things you can get in touch about yourself, } \\
\text { I mean from the inside.' }\end{array}$ \\
\hline \multirow[t]{2}{*}{ During the aerobic sports event } & Psychological effects & $\begin{array}{l}\text { 9. 'After a massage I was like focused and if I come ... nothing can distract me'. } \\
\text { 10. 'Sort of like leaves your body... it sort of like... it's likes a relaxed, beautiful feeling'. [Expressing feelings of } \\
\text { relaxation]. } \\
\text { 11. 'Uhm ... I think it actually clears your head. So you tend to ... you tend to be able to concentrate better'. } \\
\text { 12. 'Uhm ... I wasn't as nervous as I used to be, so it did help to an extent because then I was a bit calm'. } \\
\text { 13. 'I mean the confidence part of course, because you'll be able to concentrate better'. }\end{array}$ \\
\hline & Spiritual effects & $\begin{array}{l}\text { 18. 'Even spiritually I think... I think it comes with that because a lot of times, the word... its meditation, and that also } \\
\text { stems from that, you know what I mean, you know'. } \\
\text { 19. 'And it lifts your spirit as well, hey'. }\end{array}$ \\
\hline \multirow[t]{3}{*}{ After the aerobic sports event } & Psychological effects & $\begin{array}{l}\text { 20. 'And when you actually do sleep, you... you don't have... a... a... I can't explain it, but you don't have funny } \\
\text { muscles... not muscles in a way, but you can actually sleep properly. When I wake up in the morning, I don't wake } \\
\text { up with maybe... the strains and all those things, so in that way I think it actually helped'. } \\
\text { 21. 'I get very nervous to a point that I don't sleep, with massage... I was more calm, I managed to sleep, the following } \\
\text { day I would be more relaxed because I slept better'. }\end{array}$ \\
\hline & Physical effects & $\begin{array}{l}\text { 22. 'After the game you don't suffer muscle soreness anymore'. } \\
\text { 23. 'After the massage, your whole body, you feel at ease, and I would like to repute that to muscle relaxation'. } \\
\text { 24. 'You feel like a brand new person'. } \\
\text { 25. 'It tends to relax your muscles very much'. } \\
\text { 26. 'I helped with the injuries I got from playing squash'. }\end{array}$ \\
\hline & Spiritual effects & 28. 'Even spiritual, because a lot of times, the word... I felt renewed'. \\
\hline
\end{tabular}

become, the greater the possibility of discomfort or pain. He states that the pain may be experienced around injured areas. However, the pain would gradually reduce while the massage is inducing the healing process by boosting the flow of fresh blood and nutrients to the injured tissue.

Among the physical effects experienced was the fear that the stimulation might result in getting an erection (Quotation 6). However, the gender of the somatology therapist was of no concern, and the participant stated that for him the key aspect was to receive treatment that would benefit him in terms of the injuries he had sustained during previous sporting events (Quotation 7).

The findings of this study indicated that participants experienced spiritual effects. They experienced an increase in self-awareness. Massage helped create a sense of harmony and well-being, since they felt more connected with their inner self (Quotation 8). Walton (1989:89) describes spirituality as the tenure of human beings of enabling selfawareness, heightening consciousness, and providing the strength to transcend the usual self. A number of recent studies (Czech \& Burke, in press; Vernacchia, McGuire, Reardon \& Templin 2000:23) and theoretical work (Nesti, 2004:80; Ravizza 2002:18) recognise the important role that spirituality can play in enhancing sports performance. The researcher believes massage brings about or enables the link between sports performance and spirituality as mentioned by the participants in this study.

\section{During the aerobic sports event}

Psychological experiences were noted by the participants, suggesting that they were more focused prior to their performance (Quotation 9). Focusing strategies are known to play a significant role in motor performance. Individuals who use an internal focus typically show poorer outcomes of body movement than their counterparts who focus on features of the external environment (Weiss 2008:1049).

Participants felt physiologically relaxed as a result of massage during the aerobic sports event. It led them to experiencing peace of mind during their performance, since they acknowledged the preparation of their bodies for the performance during their respective sporting events (Quotation 10). The studies of Weinberg, Jackson and Kolodny (1988:202) and Hemmings, Smith and Gradon (2000:109) show significant positive psychological effects attributable to massage, regardless of the mood of the participants. Massage is believed to benefit athletes by promoting relaxation by means of biomechanical, physiological, neurological and psychological mechanisms (Leivadi, Hernandez-Reif \& Field 1998:108).

The findings of this study indicate that participants benefited, since the relaxed state of mind they experienced also transformed into a perception of improved concentration (Quotation 11). Kibler and Roreman (1983:1355) state that concentration is improved by reducing anxiety and through relaxation, and that frequent use of massage is vital for 
achieving optimum relaxing effects. The body (muscle relaxation) can therefore not be viewed separately from the mind (emotions) of an individual.

The massage was reportedly beneficial in ensuring that sportsmen were less nervous or anxious before their performance and more mentally alert and focused (Quotation 12). Research in the psychological area has reported that massage provides positive effects in the reduction of anxiety (Zeitlin, Barber, Allis \& Sullivan 2000:83).

The findings in this study indicate that after having had a massage prior to aerobic sport performances, perceived levels of confidence increased that alleviated much of the anxiety the sportsmen were exposed to (Quotation 13). Ackley and Ladwig (2005:69) emphasise that massage does in fact give an athlete a psychological boost, providing better body awareness and generating greater self-confidence.

The participants' experiences of physiological benefits somewhat overlapped with the psychological dimension. The data analysis demonstrated a perceived reduction of anxiety and a perceived increase in levels of relaxation. These perceptions were indicative of the interrelated holistic nature of the dimensions. Massage seemed to have an immediate beneficial effect on pain and mood among the participants. This perception is supported by Tessier (2005:68), who notes that massage affects athletes psychologically to the extent that they are better able to relax and focus attention on visualisation techniques for upcoming competitions.

The aspect of confidence was noted by the participants, since they perceived an increase in their confidence levels prior to their performance which in turn was demonstrated by a perceived improvement in performance (Quotation 14).

Physiological effects experienced during the aerobic sports event related to a perceived decrease in muscle tension. The participants in this study experienced that their muscle were warmer during the performance after having received a massage prior to the aerobic sports event (Quotation 15). Black, Vickerson and McCully (2003:1) state that superficial skin friction increases local heating, and consequently, causes hyperaemia within the area being massaged. Local heating increases local blood circulation. The participants also reported experiencing increased muscle and joint flexibility during the aerobic sports event, which seemed to have enhanced endurance and performance (Quotation 16). Gleim and McHugh (1997:289) define static flexibility as the range of motion available to a joint or series of joints, usually measured with a goniometer. The participants reported experiencing much less muscle cramps as a result of increased blood circulation. There were indications that the massage reduced pain in their muscles and reduced physical distress (Quotation 17). Massage may reduce pain by activating the neural-gating mechanism in the spinal cord. Tactical information from massage might stimulate large fast nerves while blocking the smaller, slower nerve fibres that detect pain. It presumably results from local lateral inhibition in the spinal cord (Guyton \& Hall 2005:79), and explains why touching a painful area is an effective strategy for relieving pain.

There were spiritual benefits experienced by the participants brought about by the massage that were reported as calmness and relaxation. They noted that it gave them a sense of well-being, which ultimately made a perceived positive contribution to their performance. It might have been as a result of the meditative benefits they had experienced from having had a massage (Quotation 18). A participant shared that he felt that his spirit was lifted (Quotation 19). In general, spirituality refers to an awareness of one's inner self and a sense of connectedness or relatedness to something greater than oneself (Reed, 1986:368). In this sense, spirituality does not refer to religious practices, specific doctrines, or denominations. Instead, it refers holistically to its integral inclusion in the physical, emotional, intellectual, social, and spiritual aspects of the human being.

\section{After the aerobic sports event}

After the aerobic sports event, the psychological benefits were largely experienced on an emotional level, since the participants reported a greater state of relaxation accompanied by a sense of tranquillity (Quotation 20). There were indications that massage had helped them with sleeping better, especially after the aerobic performance (Quotation 21). Dunlap and Writer (2012:29) attest to the fact that better sleep results from participation in aerobic sports.

Participants experienced a number of physical effects after performing in aerobic sports. They noted that they experienced less muscle pain (Quotation 22). A massage can be done after an event and after the athlete has cooled down actively and rehydrated by drinking some water. The goal of massage is to rejuvenate the body, enhance the healing process, relax tightened muscle groups, and help reduce potential soreness (Tessier 2005:67).

Participants experienced the massage as having both a relaxing and an invigorating effect (Quotations 23 \& 24). Massage was experienced as having positive effects on muscle recovery. Participants noted that they experienced discomfort for approximately the first week after their performance and after the massage. However, this did not bother them, since they experienced healing effects of massage that outweighed the initial pain (Quotation 25). The massage assisted with perceived muscle recovery and healing (Quotation 26). Massage is one of the treatments commonly used to alleviate delayed onset muscle soreness because it is thought to increase local blood and lymph flow, decrease oedema and reduce pain. Significant reduction in soreness perception of delayed onset muscle soreness after massage has been reported (Rodenburg, Steenbeek, Schiereck \& Bär 1994:414).

Spiritual effects of the massage were also experienced after performing in aerobic sports. The data indicated that the participants felt 'renewed'. Their responses created the 
impression that they felt transformed (Quotation 28). These positive responses allow a person to become a compassionate witness of his own experiences and more perceptive of new possibilities and transformation (Weinberg \& Gould 2007:150).

\section{Recommendations}

This study focused on the experiences of men of a sports massage at a somatology clinic. The data suggest that there are a number of psychological, physical and spiritual experiences that participants noted during the massage, as well as during and after the sports event. It is recommended that the findings of this study are assessed quantitatively or experimentally to validate the subjective experiences of the participants.

\section{Possible limitations of the study}

Only eight men took part in the study, and it was challenging to find participants, since the industry was reluctant to assist in this. The impression emerged that somatology clinic owners and therapists felt threatened by the study, even after consent letters were sent indicating the details of the study. It was likely that they perceived the study as a tactical means of assessing their establishments. Time was a limiting factor, since most of the men who were approached were unable to schedule an interview due to their busy lifestyles. In spite of the men meeting the selection criteria, they were often not able to express themselves very well verbally. The small sample size makes the generalisability of the results unfeasible.

\section{Conclusions}

The purpose of the study was to explore and describe the experiences of men of a sports massage at a somatology clinic prior to an aerobic sports event. Men experienced it as 'relaxing' and reported holistically beneficial effects. They described their experiences during the massage, as well as during and after participation in the aerobic sports event. Psychological, physical, and spiritual effects were reported. On a psychological level, participants generally perceived a reduction in stress, a decrease in nervous tension and anxiety, and improved concentration. On a physical level, participants felt that, although the massage was painful at times, there was a reduction in muscle stiffness, less cramping and soreness and less trouble from previous injuries. Spiritually, participants experienced a sense of renewal, greater harmony, more self-awareness and tranquillity. The insight gained from this exploration may assist somatologists in providing an optimal massage experience for men who are visiting somatology clinics. As the trend of men visiting somatology clinics becomes more established, men might feel more comfortable in a domain that has previously been viewed as exclusively female.

\section{Acknowledgements}

The authors acknowledge the University of Johannesburg for financial support to V.K. The editor Andrè Hills is acknowledge with his assistance in the final reading of the report.

\section{Competing interests}

The authors declare that they have no financial or personal relationship(s) which may have inappropriately influenced them in writing this article.

\section{Authors' contributions}

K.J. (University of the Western Cape) was the supervisor and initiated the writing of the article. J.M. was the cosupervisor (University of South Africa) and cowriter in the revised article and V.K. (University of Johannesburg) was the master's student and researcher in the study.

\section{References}

Ackley, B.J. \& Ladwig, G.B., 2006, Nursing diagnosis handbook: A guide to planning care, Mosby, Michigan.

Aldrade, C., \& Clifford, P., 2008, Outcomes-based massage: From evidence to practice, 2nd edn., Lippincott Williams \& Wilkins, Michigan.

Babbie, E. \& Mouton, J., 2001, The Practice of Social Research, Oxford University Press, Cape Town.

Benor, D.J., 2004, Consciousness, bioenergy and healing: Self-healing and energy medicine for the 21st century, Wholistic Healing, New York.

Black, C., Vickerson, B. \& McCully, K., 2003, 'Non-invasive assessment of vascular function in the posterior tibial artery of healthy humans', Dynamic Medicines 2(1), 1. http://dx.doi.org/10.1186/1476-5918-2-1, PMid:12628021 PMCid:151670

Brennan, M. \& Heisser, D., 1988, Spiritual assessment and intervention with older adults: Current directions and applications, The Haworth Pastoral Press, New York.

Burns, N. \& Grove, S.K., 2005, The practice of nursing research: Conduct, critique and utilization, 5th edn., Elsevier, Philadelphia.

Callagan, M., 1993, 'The role of massage in the management of the athlete: A review' British Journal of Sport Medicine 27 (1), 28-33. http://dx.doi.org/10.1136/ bjsm.27.1.28

Coffey, I.H., 2004, 'A descriptive study of experiences in organizing and teaching a special class for mentally retarded children in the Leitchfield Independent School', University of Louisville 6, 325

Collins, K.M., Onweugbuzie, A.J. \& Jiao, Q.G., 2010, Toward a broader understanding of stress and coping: Mixed methods approaches, Library of Congress Cataloguingin-Publication Data, Washington.

Concise Oxford English Dictionary, 2004, C. Soanes \& S. Angus (eds.), 12th edn., Oxford University Press, New York.

Creswell, J.W., 2003, Research design: Qualitative and quantitative approaches and mixed methods approaches, Sage, London.

Creswell, J.W., 2007, Qualitative inquiry \& research design: Choosing among five approaches, 2 nd edn., Sage, Thousand Oaks.

De Vos, A.S., Strydom, H., Fouché, C.B. \& Delport, C.S.L., 2005, Research at grassroots., Van Schaik, Pretoria.

Denzin, N.K. \& Lincoln, Y.S., 2005, Handbook of qualitative research, 2nd edn., Sage, Thousand Oaks. PMCid:1088373

Draper, D.O. \& Tessier, D.G., 2005, 'Sport massage: An overview', Athletic Therapy Today 10(5), 67-69.

Dunlap, L. \& Writer, S., 2012, 'Cycling', Mobility Forum: The Journal of the Air Mobility Commands Magazine, 18 July, n.p.

Flick, U., 2009, An introduction to qualitative research, 4th edn., Sage, London.

Gleim, G.W. \& McHugh, M.P., 1997, 'Flexibility and its effects on sports injury and performance', Sports Medicine 24(5), 289-299. http://dx.doi. org/10.2165/00007256-199724050-00001, PMid:9368275

Goodwin, I.C., 2009, 'The relationship perceived wellness and stages of change for exercise among rural African American women', Nursing Dissertations, viewed 16 March 2013, from http://digitalarchive.gsu.edu/nursing_diss/9

Gould, F., 2004, Body massage for holistic therapists, Nelson Thornes, London.

Green, J. \& Thorogood, N., 2009, Qualitative methods for health research, 2nd edn., Sage, London.

Guyton, A.C. \& Hall, J.E. 2005, Textbook of medical physiology, 11th edn., Saunders Elsevier, Philadelphia.

Hamill, C. \& Sinclair, H., 2010, 'Bracketing - Practical considerations in Husserlian phenomenological research', Nurse Researcher, 17(2), 16-24.

Hart, J.M., Swanik, C.B., \& Tierney, R.T., 2005, 'Effects of sport massage on limb girth and discomfort associated with eccentric exercise', Journal of Athletic Training 40(3), 181-185. PMid:16284638 PMCid:1250257

Harvard Men's Health Watch, 2006, 'Massage therapy', September, p. 6.

Hemmings, B., Smith, M. \& Gradon, J., 2000, 'Effects of massage on physiological restoration, perceived recovery, and repeated sports performance', British Journal of Sports Medicine 34, 109-115. http://dx.doi.org/10.1136/bjsm.34.2.109, PMid:10786866 PMCid:1724183 
Holey, E.A. \& Cook, E.M., 2003, Evidence based massage: A practical guide for therapists, 2nd edn., Churchill Livingstone, Philadelphia.

Kibler, V.E. \& Roreman, R.J., 1983, 'Effects of progressive muscle relaxation training on trait anxiety', Journal of Sport Psychology 1, 1355.

Krefting, L., 1991, 'Rigor in qualitative research: The assessment of trustworthiness', American Journal of Occupations Therapy, 45(3), 216.

Krieger, D., 1996, Therapeutic touch inner workbook: Ventures in transpersonal healing, Donnelley, Chicago.

Leary, M.R. \& Tangney, J.P., 2003, Handbook of self and identity, The Guilford Press, New York.

Leivadi, S., Hernandez-Reif, M. \& Field, T., 1999, 'Massage therapy and relaxation effects on university dance students', Journal of Dance Medicine Science, 3(3), 108-112.

Maree, K. \& Ellias, M. 2007, Educating people to be emotionally intelligent, Praeger, New York.

McMahon, R. \& Pearson, A. 1998, Nursing as therapy, 2nd edn., Nelson Thornes, London.

Mouton, J. 2001, Understanding social research, Van Schaik, Paarl.

Moyer, R. \& Diem, H., 2004, Community health nursing projects: Making a difference. Lippincott Williams \& Wilkins, Philadelphia.

Onwuegbuzie, A.J., Leech, N.L. \& Collins, K.M.T., 2008, 'Interviewing the interpretive researcher: A method for addressing the crises of representation, legitimation and praxis', International Journal of Qualitative Methods 7 (4), 1-17.

Pike, G., 1997, Sport massage for peak performance, Harper-Collins, New York.

Reed, P.G., 1986, 'Developmental resources and depression in the elderly', Nursing Research,. 35, 368-374. http://dx.doi.org/10.1097/00006199-198611000-00014, PMid:3640355
Rodenburg, J.B., Steenbeek, D., Schiereck, P. \& Bär, P.R., 1994, 'Warm-up, stretching and massage diminish harmful effects of eccentric exercise', International Journal
of Sports Medicine, 15(7), 414-419. http://dx.doi.org/10.1055/s-2007-1021080, PMid:8002121

Sayre-Adams, J., Wright, S.G. \& Billey, F.C., 2001, The theory and practice of therapeutic touch, 2nd edn., Harcourt, San Diego.

Singleton, R., Straits, B.R., Straits, M.M., \& McAllister, R.J., 1988, Approaches to socia research, Oxford University Press, New York.

South Africa, 1982, The Allied Health Professions Act, 63 of 1982, Government Printers, Pretoria.

Tessier, P., 2005, 'Acute effects of pre-event lower limb massage on explosive and high speed motor capacities and flexibility. Journal of Sport Science and Medicine 7, 549-555.

Wall, C., Glenn, S., Mitchinson, S. \& Poole, H., 2004, 'Using a reflective diary to develop bracketing skills during a phenomenological investigation', Nursing Researcher 11(4), 20-27.

Weerapong, P., Hume, P. A. \& Kolt, G.S., 2005, 'Pre-exercise strategies: the effects of warm-up, stretching, and massage on symptoms of eccentric exercise-induced muscle damage and performance', Ph.D. thesis, School of Nursing, Auckland University of Technology 5:235-245.

Weinberg, R. \& Gould, D., 2007, Foundations of sport and exercise psychology, 5th edn., John Champaign Illionois.

Weinberg, R., Jackson, A. \& Kolodny, K. 1988, 'The relationships of massage and exercise to mood enhancement', Sport Psychology 2, 202-211.

Weiss, M.R., 2008, 'Head over heels with success: The relationship between selfefficacy and performance in competitive youth gymnastics', Journal of Sport \& Exercise Psychology 11(4), 1049.

Zeitlin, S., Barber, C., Allis, C. \& Sullivan, K., 2000, 'Differential regulation of CENP-A and histone $\mathrm{H} 3$ phosphorylation in G2/M', Journal of Cell Science 114, 83. 